\title{
Determination of Export Price by Incoterms 2010 (Study in PT X Karawang)
}

\author{
Rima Sundari \\ Politeknik Pos Indonesia \\ rimasundari@rocketmail.com \\ Edi Supardi \\ Politeknik Pos Indonesia
}

\begin{abstract}
Determination of export price will give influences to company's profit, image, and the competitiveness in the customers perspectives. Determination of export price must be based on the applied international standards which refer to the International Commercial Terms or Incoterms. Incoterms always updated to follow developments of international trading therefore any Incoterms changes that occur will affect the determination. The calculation of export price based on Incoterms is calculated based on cost of goods production, benefits, cost of packaging, loading costs, transportation, taxes and fees and the cost of transportation insurance. The results showed that most often-used Incoterms by company in gradation are FOB, CFR and CIF. Lastly, the higher use of Incoterms class by company has positive influence to increase corporate profit.
\end{abstract}

Keywords: Determination of export price, Incoterms, profit

\section{INTRODUCTION}

PT. $\mathrm{X}$ is a manufacturing company whose main activities are in the production of rubber material parts. Its main activity is to purchase raw materials from local and import, incluing design types of parts that would be created to produce and finished goods.

PT. X performs the sale of small-part production of spare parts within the country (domestic). Most of the production is to export them abroad, such as to Japan, America, Europe and most of the Asias. For export sales, the highest price is FOB, CFR, and CIF.

Incoterms is an acronym for International COmmercial TERMS. These terms were developed by the International Chamber of Commerce (ICC) (Roberto Bergami, 2012).

Inc terms are recognized by UNCITRAL as a global standard for interpreting the terms in foreign trade and provide internationally accepted rules specifying (Lazar, 2011).

Incoterms is a codification of international regulations for the uniformity of the interpretation of the contract clauses in international trade (Suyono, 2003)

Based on the three definitions above, it can be concluded that Incoterms stands for International Commercial Terms or the "Terms" in "International" "Commercial" Trade, i.e. a codification of international regulations for the uniformity of contract interpretation in international trade that includes the rights and obligations of cost, risk, insurance and where the handover of goods between the seller and buyers.

In the following customer request, PT. X applies the calculation of export price based on the terms of the latest incoterm i.e. Incoterms 2010, according to the basis of the interest to calculation analyis of export selling price based on Incoterms 2010. In this research, the discussion will further focus on how the determination of export price is calculated or specified by the company and the type of the use of most profitable Incoterm for exporters.

The formulation of the problem in this research is how the determination of the selling price of exports by Incoterms 2010 in the company and its effects on corporate profits.

\section{METHOD}

The type of research used in this research is a case study - research about the status of the subject of the research regarding a specific phase or typical of the entire personalitas, therefore it will be able to provide a detailed description about the background, the attributes and the characters that become peculiar in a case, either individual or in general.

PT. $X$ is an exporter applying the calculation of the export selling price by various incoterms. There 
are eleven incoterms types which three of them are most used, that are FOB, C\&F and CIF. Incoterms FOB is a type of one of the most used by PT. X, same with other exporters in Indonesia in general, therefore it can also represent cases of incoterms determination by Indonesian exporters in general.

The data source in this research is a secondary data: data that has been processed further and presented by either collector party or other parties existing in the company, in the form of export price data in PT. X.

In this research, data collection method carried out by the author is a field survey method. The survey is completely done by observing directly the company which is also research subject. In the form of documentation technique, field survey is a technique of data collection by checking or seeing directly the documents, notes, and the books used by the company. In this research, the data obtained in the form of export is cost data in the accounting section. Supporting documents were also obtained as well as the background of the specific incoterm estabilished from the marketing export section including Quotation, Sales Contract, Invoice, Insurance, COO and other documents that become the background of overseas importer or buyer assigning specific Incoterm.

"Export is a step by step that must be taken by exporters from promoting for their merchandise to the buyer, asking price offer, create a contract selling exports, send goods sold to the buyer to receive payment from the buyer" (Amir M.S, 2008).

Price is the amount of money (plus some products if possible) that is needed to get a number of a combination of products and its service (Swastha, 2009).

Based on the definition, price is also able to be understood as a value as a value in the form of money that must be spent by the buyer to get the product and services that included with the product.

In the export transaction, there are some components that make up the market price (Amir M.S, 2008). These components are in the following:

1. The procurement cost, including: a) The costs of production consisting of Material Cost, Labor Cost and General Overhead Cost, b) The value of Purchase Goods.

2. Management cost: a) Packaging Cost consisting of Packaging Material, Packing Fee and the Cost of Printing/marking/trade marks, b) Fee of deporting from warehouse to the warehouse door, c) Fee of loading goods from warehouse door to the transportation or into container, d) Transport cost from warehouse until the deposition to the side of the ship or terminal or container dock, e) Fee of loading goods from the dock to the ships, f) Fee of renting a warehouse, container, shipping charges, fee of the port loading and disassemble, g) And others.

3. The gleanings of the country, including: a) Pajak
Ekspor and Pajak Ekspor Tambahan (PE/PET), b) Goods Duty, c) Value Added Tax.

4. Third Party Services, including: a) Cost of transportation services, b) Provision and bank rate, c) Insurance Premium, d) Cost of surveyor, e) Cost of quality certification, f) Cost of certificate of origin, g) Cost of health certification, h) Cost of quarantine certification, i) Cost of certification of weights, j) Other certification costs.

In addition to the calculation, first of all we need to add profit or gain of export goods that we sell. Second step to calculate the profit is to input the calculation of the incoterms as the selling price of the export goods.

Swastha (2009) share determination method into two i.e. : 1) Cost-plus pricing method sets the selling price for one unit of goods which is the same with the amount of the cost per unit plus a number of to close the desired profit (called margin) on the unit. The formula is Total Cost + Margins $=$ Selling Price, 2) Mark-up referral method sets the selling price for one unit of goods based on the purchase price plus the profit, generally used by the non manufacturer/ producer merchants. Purchase Price + Mark Up $=$ Selling Price.

According to the profit determination (Amir M.S, 2008) establishes two types of profit determination, i.e: 1) Progressive Method is a determination method of export profit which first calculate the amount of goods cost, add the approximate percentage of profit as the basis of determination of the selling price that the exporters will offer to buyers (importers). Generally used to determine the price of export commodities with high competitiveness. Cost of Goods + Profit $=$ Selling Price, 2) The traditional or retrograde method is a method used for certain commodities such as rubber, coffee, and others where the profit in the countdown due to the selling price has been determined by the international commodity exchange controlled by importers. Selling Price - Price $=$ Profit .

Based on Amir M.S's notation (2008) there are four ways to determine selling price of export i.e.:

1. Cost + Mark-Up is selling price determined on the basis of cost plus profit.

2. Current market price is selling price determined on the basis of the willingness of the buyer in accordance with the applicable international prices in international commodity exchange.

3. Susidized Price is selling price for export based on the cost of reduced subsidies. The subsidies could be the elimination of overhead, the return of ex import raw material import duty, or import tariff entering the destination country such as Generalized Systems of Preference (GSP).

4. Dumping is selling price determined lower than the selling price of a commodity that is the same for the domestic market. 
Incoterms is a codification of international regulations for the uniformity of the interpretation of contract clauses in international trade.

Incoterms contains a set of conditions clauses of delivery of goods in international trade that basically set 3 things, i.e. cost, risk, and responsibility. Cost in exports is the cost that must be borne by each party (seller and buyers) in order to deliver goods until it reaches its agreed destination. Seller must know the cost to which point the delivery of goods is sent. Likewise, buyers should also know the cost to which point in the delivery of goods is sent. Risk is the possibility of losses arising from the delivery process of exports. This risk can be any damaged, lost, degradation, or cost that may arise outside the cost that has been agreed. Responsibility is arrangement task (e.g., permissions export document, import document) arising in the process of delivery of goods (Astuti Purnamawati, 2013).

In the international transaction mechanism, the use of terms on Incoterms stated clearly in the trade contract (Astuti Purnamawati, 2013). The terms and conditions listed in the Incoterms can be used for:

1. Completing the international transaction in the form of tangible goods, not including discounted rates of intangible goods (e.g., computer software transaction, services, etc.

2. Showing the obligations of each of the parties involved in the trade contract related to: a) The time of delivery of goods, b) Organizing the formality of international trade, c) The determination of the type and conditions of transportation of goods to the destination, d) Shipping requirements and evidence of delivery, e) Distribution of load (costs, collections) in between parties that transact.

3. Setting the requirements for transportation and delivery of goods in brief. The type of transportation used to send exported goods can be in the form of land transportation (train or truck), air transportation and water transportation (sea and river).

Incoterms will avoid the possibility of misunderstandings between the parties involved in the export import as a result of the difference in transaction practices in the state between seller and buyer's country. (Astuti Purnamawati, 2013). Incoterms 2010 issued in English as the official language and 31 other languages as official translations. In incoterms 2010, there are only 11 simplified terms from 13 term Incoterms 2000 by adding 2 new terms and replace 4 old terms. The new term in incoterms 2010 are Delivered At Terminal (DAT) and Delivery At Place (DAP). Those which have been replaced are Delivered At Frontier (DAF), Delivered Ex Ship (DES), Delivered Ex Quay (DEQ), Delivered Duty Unpaid (DDU) (Susilo, 2013).

Incoterms 2010 is divided into 2 categories based on delivery method, i.e. 7 terms applies in general and 4 terms applies specifically for delivery through sea transportation. As a review, the 13 terms in the Incoterms 2000 i.e.:

1. EXW (place name): Ex Works, the seller determines where he/ she should be taking of goods.

2. FCA (place name): Free Carrier, the seller is only responsible to arrange the export permission and deliver the goods to the party carried in the place that has been determined.

3. FAS (departure port name): Free Alongside Ship, the seller is responsible until the goods are located in the port of departure and ready at the side of the ship to load. It only applies to water transportation.

4. FOB (departure port name): Free On Board, the seller is responsible to arrange export permission to load goods in the ship that is ready to go. Only applies to water transportation.

5. CFR (destination port name): Cost and Freight, the seller bears the cost until ship with loaded goods arrived at the destination harbor, but the responsibility of only until the time when the ship departs from the port of departure. It only applies to water transportation.

6. CIF (destination port name): Cost, Insurance and Freight, like CFR with an addition, the seller is obligated to pay for the insurance of goods sent. Only applies to water transportation.

7. CPT (destination place name): Carriage Paid To, the seller bear the cost until the goods arrive at the destination, but the responsibility of only until the time of goods delivered to the transporter.

8. CIP (destination place name): Carriage and Insurance Paid to, like CPT with an addition, the seller is obligated to pay for the insurance of goods sent.

9. DAF (place name): Delivered At Frontier, the seller arrange export permissions and responsible until the goods arrive at the border of the destination country. Customs and import permission to become the responsibility of the buying party.

10. DES (destination port name): Delivered Ex Ship, the seller is responsible to the ship with loaded goods arrived at the destination harbor and ready to disassembled. The import permission became the responsibility of the buying party. It only applies to water transportation.

11. DEQ (destination port name): Delivered Ex Quay, the seller is responsible to the ship with loaded goods arrived at the destination harbor and the goods has been disassembled and stored in the dock. The import permit became the responsibility of the buying party. It only applies to water transportation.

12. DDU (place name purpose): Delivered Duty Unpaid, the seller is responsible for transporting goods up to the destination, but not including the cost of insurance and other costs that may arise as the cost of imports, customs and tax from the country of the buying party. The import permit became the 
responsibility of the buying party.

13. DDP (destination place name): Delivered Duty Paid, the seller is responsible for transporting goods up to the destination, including the cost of insurance and all other fees that might appear as the cost of imports, customs and tax from the country of the buying party. The import permit also became the responsibility of the seller.

As has been described previously, from 11 category in the Incoterms 2010, there are only two new categories i.e. DAT and DAP. Following are the explanations:

Delivered at the Terminal (DAT)

- This terms can be used for the delivery of goods done by using the multimoda transport.

- Seller delivered goods to buyers in the terminal at the time of goods arrive at the destination port or destination place.

- The terminal is including the pier, warehouse, Container Yard (CY), railway station or terminal in the airport.

- Both sides (seller and buyers) agreed that the desired terminal is the place where the transition from the seller risk to the buyer.

- When the seller means to bear all the cost and risk from the terminal to other certain point, alternative DAP and DDP can be used.

Delivered at Place (DAP)

- This terms can be used for delivering goods. It can be done by using the the multimoda transport.

- Seller delivered goods to buyers in the terminal by the time of goods arrive or ready to disassemble at the destination.

- Both sides (seller and buyers) are recommended to determine as descriptive as possible the point where the agreed destination, because at this time the risk will switch from the seller to the buyer.

- When the seller means to bear all costs and risks to the goods expenditures, pay taxes, etc., it can be considered as use Delivered Duty Paid (DDP).

Incoterms have been grouped into 4 categories:

First : ("E" Terms-Ex work), seller delivered goods to the place by their own.

Second : ("F" Terms, FCA, FAS, and FOB), seller delivered goods to the place appointed by the buyers.

Third : " $C$ " Terms), seller sign the trasnportation contract without bearing the risk of loss or damage of goods or additional charges occured after shipping (CFR, CIF, CPT and CIP).

Fourth : ("D" Terms), seller bear the cost and risk that requiring or arising in the transport of goods to the destination country (DAF, DES, DEQ, DDU, and DDP).

In the international transaction, delivering goods by using the Incoterms is basically related to the responsibility for goods that are traded. In the process
Table 1. Incoterms 2010

\begin{tabular}{ccc}
\hline GROUP E & EXW & Ex Works \\
\hline GROUP F & FCA & Free Carrier \\
MAIN & FAS & Free Alongside Ship \\
CARRIAGE & FOB & Free On Board \\
UNPAID WAGES & & Cost And Freight \\
\hline GROUP C & CFR & Cost Insurance and freight \\
MAIN & CIF & Carriage Paid To \\
CARRIAGE PAID & CIP & Carriage and Insurance Paid \\
& DAF & To \\
\hline GROUP D & DES & Delivered At Frontier \\
ARRIVAL & DEQ & Delivered Ex Quay \\
& DDU & Delivered Duty Unpaid wages \\
& DDP & Delivered Duty Paid \\
\hline
\end{tabular}

of delivering goods from the seller (exporters) until into the hands of the buyers (importers), there are 11 obligations (Astuti Purnamawati, 2013).

1. Preparing the land transportation in the seller's country to the main transportation

2. Arranging the export formality in the seller's country

3. Paying taxes and levies from others in the seller's country

4. Loading to main transportation in the seller's country

5. Paying for the cost of the main transportation

6. Arranging and paying for transportation insurance

7. Disassembling goods from main transportation in the buyer country

8. Arranging the formality of imports in the buyer country

9. Paying taxes and fees collected in the buyer country

10. Preparing the land transportation in the buyer's country

11. Bearing the cost and other risk in buyer's country.

Ex Works (EXW) represents the obligation of the seller at a minimum, where the obligation of the seller is limited to deliver goods in the warehouse of the seller (Lazar, 2011).

Free Carrier (FCA) means that the seller delivers goods to the carrier or another person nominated by the buyer at the seller or other place designated (Lazar, 2011). It means the seller is required to send goods into the transporter or someone who insist that has been determined by the buyers.

The terms of delivery of goods of FCA can be used for the type of land, air and multimoda transportation. The terms of FCA is not used in the delivery of goods exports using water transportation. Multimoda transportation 
is carry using some kind of transportation (e.g. trucks, containers, then train). Transport means everyone in the transportation contract, who is responsible to carry or guarantee to carry, better to use the train through the highway transportation, or with a combination of transportation. If the buyers point people other than the main carrier to receive the goods, the seller is considered to have been fulfilled its obligations after the seller delivered goods to the person appointed by the buyer earlier. Writing the delivery of goods with FCA in trade contract: FCA (the contents of the name of the place of the handover in the seller country) Incoterms ${ }^{\circledR} 2010$ (Astuti Purnamawati, 2013).

Carriage Paid To (CPT) means the seller delivered goods to the company noted that the main itself, so that all costs required to carry to the destination that has been determined over the responsibility of the buyer. After the delivery of goods by the seller to the buyer, all costs, collections and risk that arise in the journey toward the buyer becomes the responsibility of the buyer (Astuti Purnamawati, 2013).

Carrier means that everyone who is responsible for transportation contract do or guarantee the implementation of transport with trains, road, Air, Sea, the river or a combination of transportation.

Organizing the export formality on the terms CPT done by the seller. This handover conditions can be used on the air transportation, on land and use some kind of transportation (various) required until the goods to escort purpose (multimoda transport). Writing how the delivery of goods with CPT in trade contract: CPT (the contents of the name of the place of the handover in the buyer country) Incoterms ${ }^{\circledR} 2010$.

Carriage and Insurance Paid To (CIP) means the seller delivered goods to the transport company that they pointed themselves, so that all costs required to carry to the destination that has been determined and insurance against the risk of delivery of goods to the destination over the responsibility of the buyer. After the transfer of goods by the seller to the buyer, all costs, collections and risk that arise in the journey toward the buyer becomes the responsibility of the buyer (Astuti Purnamawati, 2013).

The handover of CIP conditions require the seller to pay for the cost of insurance against the risk of goods. But usually the risk insured is only a minimum. If the buyer wants the wider, then the cost of insurance becomes the responsibility of the buyer.

Carrier means that everyone who is responsible for transportation contract do or guarantee the implementation of transport with trains, road, Air, Sea, rivers or a combination of transportation.

If the handover of goods using some kind of transportation, then all risks to the sent items are given to the first transportation company. The handover of CIP conditions require the seller to arrange the export formality. CIP conditions can be used for transportation air, land and transportation of various vehicle (multimoda transport). Writing the delivery of goods with CIP in trade contract: CIP (the contents of the name of the place of the handover in the buyer country) Incoterms ${ }^{\circledR} 2010$.

Delivered at the Terminal (DAT) means the seller has an obligation to deliver goods in the terminal that has been specified in the arrival port. The terminal in this case is including the port, warehouse, container yard $(\mathrm{CY})$, train terminal or a terminal in the airport. All costs, collections and risk that arise, except customs and import tax and other costs in the destination port due to the delivery of goods to disassemble to be handed over to the terminal that has been specified in the destination port are the responsibility of the seller. The Buyer obligated to bear the customs and tax and other levies and will bear the consequences if fail to arrange the formality of imports on time (Astuti Purnamawati, 2013).

Customs and import tax and administrate the import formality can only done by the seller on the agreement both sides. But this needs to be clearly defined in the trade contract. DAT conditions of the handover used for any transportation. Writing the delivery of goods with DAT in trade contract: DAT (the contents of the name of the terminal where the handover of goods in the arrival port) Incoterms $\AA 2010$.

Delivered at Place (DAP) means the seller has an obligation to deliver goods in the place that has been determined in the buyer country on the condition of the items ready to disassemble. All costs, collections and risk that arise, except customs and import tax and other costs after the goods delivered in the place that has been determined to become the responsibility of the seller. The seller is only responsible for delivering the goods to the place which has been agreed in the buyer country in the condition of goods which has not been disassembled. Thus, delivering goods with DAT, buyers obligated to bear the customs and tax and other levies and will bear the consequences if fail to arrange the formality of imports on time (Astuti Purnamawati, 2013).

Customs and import tax and administrate the import formality can only be agreed by the seller. But this needs to be clearly defined in the trade contract. Writing the delivery of goods with DAP in trade contract: DAP (the contents of the name of the place of delivery of goods in the buyer country) Incoterms ${ }^{\circledR} 2010$.

Delivery Duty Paid (DDP) means delivery of goods is done by the seller at the place that has been determined by the parties related. All costs, collections, and the risk of goods during the journey to the destination is the responsibility of the seller. Obligations of the seller only delivering goods to the place that has been mentioned and goods still on top of transportation. The Buyer obligated to bear the costs of goods disassemble from transportation (Astuti Purnamawati, 2013).

DDP conditions can be used for any transportation, 
land transportation, air transportation, sea transportation, rivers transportation or use many transportations (various). Conditions of delivery of goods using DDP is the reverse conditions with the delivery of goods using EXW. On the conditions of DDP describes the responsibility on the buyer and EXW terms describes the minimum responsibility on the seller.

An example of the use of the Delivery Duty Paid terms delivery of goods in trade contract written DDP Cairo Incoterms ${ }^{\circledR 2} 2010$. This means that the seller has an obligation to deliver goods to the buyer in the city of Cairo (Egypt) as the point of delivery of goods.

Free Alongside Ship (FAS) means the seller delivered goods in the side of the ships for the port of departure. The seller has an obligation to arrange the export formality (on incoterm before incoterms 2000, which arrange the formality of exports is the buyer) and bear all costs and fees generated from the delivery of goods to the side of the transporter ship. The risk of damage to the goods and the cost that arise after the handover is the responsibility of the buyer (Astuti Purnamawati, 2013).

In terms of FAS, it is possible for everyone to arrange the formality of exports, including importers. If it is the agreement between the seller and buyer, it must be asserted in export trade contract. The handover conditions only applies to the delivery of goods exports using the ships through the sea and the river only.

In general, distribution of the responsibility on the handover of goods exported using the terms of FAS is that the seller is responsible for providing land transportation in the exporters country (drive to destination country/ state borders transportation; and arrange the export formality in country). Buyer (importers) is responsible for other taxes and fees in the exporters country; exporters loading to main transportation; main transportation cost; transportation insurance; charges of disassemble from main transportation; import formalitys in the exporters country and other taxes and fees in the importer country; land transportation in importer country; and other cost and risk in importer country.

An example of the use of the Free Alongside Ship terms delivery of goods written on the trade contract are the FAS Tanjung Mas Incoterms 2010. This statement means that the seller delivered goods to the buyer in Tanjung Mas. Tanjung Mas port is a departure port to the buyer country.

Free On Board (FOB) means delivery of goods by the seller to the transport ship in the port of departure (port of shipment). The seller has an obligation to bear the costs, collections, and the risk of delivery of goods to the ship that is determined by the buyer. Organizing the formality of exports to the handover using FOB done by the seller (Astuti Purnamawati, 2013).

With the FOB terms, the seller is responsible for providing land transportation in the exporters country (driving to destination country/state borders transportation; arranging the export formality in exporters country; paying other taxes and fees in the exporters country; and loading of goods to main transportation). Buyer (importers) is responsible for main transportation cost; transportation insurance; disassembling charges from main transportation; importing formality in the exporters country and other taxes and fees in the importer country; land transportation in importer country; and other cost and risk in importer country.

An example of the use of the Free On Board terms delivery of goods written on the trade contract is FOB Tanjung Mas Mas Incoterms $® 2010$. This statement means that the seller delivered goods to the buyer at the top of the ship that docked Tanjung Mas port. Tanjung Mas port is a departure port to the buyer country. The cost of the warehouse to save the goods while waiting for the transport ship to arrive becomes the responsibility of the seller.

Cost and Freight (CFR) means the seller delivered goods to pass through the fence of the ship at the port of departure. The seller has an obligation to bear all costs and collections after the goods out of the fence of the ship at the port of departure. But the risk of damage, lost, and other risk, over sent goods has become the responsibility of the buyer (Astuti Purnamawati, 2013).

With the CFR terms, the seller is responsible for providing land transportation in the exporters country (drive to destination country/state borders transportation; arrange the export formality in exporters country; paying taxes and fees in other exporters country; loading goods into main transportation; main transportation costs; and disassembling cost from main transportation. Buyer (importers) is responsible for transportation insurance; formality imports in the exporters country and other taxes and fees in the importer country; land transportation in importer country; and other cost and risk in importer country. Conditions of the handover with CFR can only be used for sea and river transportation only.

An example of the use of the Cost and Freight terms writtern in trade contract is CFR Karachi Incoterms $® 2010$. This means that the seller has an obligation to deliver goods to the port of Karachi as the port of goods arrival (Port of Destination). The handover of exports in this way often also shortened by C\&F.

Cost, Insurance, and Freight (CIF) means the seller has an obligation to deliver goods to pass through the ship fence at the port of departure. The parties involved in the transaction agreed to redirect the risk of damage, loss, and the risk of another over the goods that are sent to the third party, i.e. the insurance company. Thus, in the conditions of delivery of goods using CIF, seller obliged to bear all costs, collections after the goods out of the ship fence at the port of departure, including the cost of insurance against the risk of delivery of goods (Astuti Purnamawati, 2013).

With the CIF terms, the seller is responsible 
for providing land transportation in the exporters country (driving to destination country/state borders transportation; arranging the export formality in exporters country; paying taxes and fees in other exporters country; loading goods into main transportation; the cost of the main transportation; transportation insurance cost; and teardown of main transportation). Buyer (importers) is responsible for the formality of imports in the exporters country and other taxes and fees in the importer country; land transportation in importer country; and other cost and risk in importer country. Conditions of the handover with CIF can only be used for sea and river transportation only.

An example of the use of the Cost, Insurance, and Freight terms delivery of goods in trade contract is written as CIF Shanghai Incoterms 2010. This means that the seller has an obligation to deliver goods to the port of Shanghai as the port of goods arrival (Port of Destination).

The explanation of each type of incoterm can be seen in the Figure 1.

The Calculation of the Selling Price Based on Incoterm 2010, to easily understand the calculation of selling price based on the following incoterms, the following is an illustration example of the terms, especially for CIP terms. Point assumption is CIP warehousing area in the port of destination. In this CIP terms, the costs become the responsibility of exporters (seller) which include (Surono, 2012): a) Export Packing, costs of export packaging, b) Export Clearence, license and other authorizations (cost of export formality, export permits and forms of formal obligation from the government), c) Inland Freight, (land transportation costs from sellers's location to the port/ terminal), d) Loading Charges and Terminal Charges, (loading costs including the cost of goods in the departure port handling), e) Freight, (the costs of goods transportation trip, often from the port of departure to the destination port), f) Insurance, (premium insurance; main transportation in the minimum amount of cover, except in other agrrement), g) Destination Arrival Charges, (costs of ship handling at the arrival port, but not including the cost of disassemble).

Then the responsibility of the seller will cover the cost of: h) Unloading Charges, (disassemble goods cost from the main transporter means), i) Import Customs Interior, (cost settlement of formality of import customs, such as PPJK services, import license arrangement, and others), j) Duty and taxes, (collections of import duties and taxes in order to import), k) Delivery to destination, (the cost of land transporting until they came to the destination place of importers).

Attached to the explanation of the responsibility for costs for the seller versus buyer in Figure 2.

The thesis statement of this research is that the basic structure in the company currently covers the cost of production, management costs and third party services, while the company does not count the cost of the levy of the State due to the VAT export is $0 \%$, because the company always include PEB in exports and the export is done in the name of the company itself (PT.X), therefore the cost outline and profit forming are as followed:

1. The cost of the container deport i.e.: cost that covers the administration costs and Lift On (raise) container from depot to top trucks,

2. Material Cost,

3. Labor Cost,

4. General Overhead Cost,

5. Packaging Material,

6. The cost of label print,

7. The cost of Stuffing: cost to move and arrange the goods from the warehouse to the loading location,

8. The cost of Loading i.e.: loading costs from the warehouse into the Containers,

9. Transportation/Trucking cost from Karawang to port,

10. The cost of Customs Clearence i.e. the cost of export permission settlement process into the port,

11. The cost of the Port : fees occurred in the port including the cost of the cumulation (Storage) and lift off (dropping the container from the truck to the floor port),

12. THC cost (Terminal Handling Charge) cost load from the port to the ship,

13. The cost of $\mathrm{B} / \mathrm{L}$ Fee i.e. : the cost of issuing the bill of landing document,

14. The cost of making the Certificate of Origin document,

15. The cost of Surveyor i.e. the cost required to get the inspection certificate/Certificate of Inspection,

16. The cost of Ocean Freight i.e. : the cost of shipping from the port of load Jakarta, Indonesia to the destination port in Japan,

17. Insurance Premium, i.e. : the cost of closing of the vehicle insurance premium export goods,

18. Bank Rate. It is set at $12 \%$ per year, where an average of one-time cycle from the beginning of the production of raw material purchase until the payment is by 3 months and applies to the three types of incoterms the company used currently i.e. FOB, CFR and CIF, due to the method of payment using L/C (Letter of Credit), therefore PT. X as exporters will get the payment immediately after the document is handed over to the banks,

19. Profit, i.e.: the benefits expected by the company, method used by the company is currently a progressive method, with the base of the determination of net profit 15 percent of the total cost of that issued. Basis of calculation are as follows:

a. Incoterm FOB : profit $15 \%$ multiplied by the amount of the cost of 1 to 15 plus the bank rate,

b. Incoterm CFR : profit $15 \%$ multiplied by the amount of the cost of 1 to 16 plus the bank rate, 
c. Incoterm CIF : profit $15 \%$ multiplied by the amount of the cost of 1 to 17 plus the bank rate,

The following is the calculations with the type and number of prices of goods which are most common types of goods X sent in the 1X20' Containers (or 20 feet container). Because the data is the company's secret, the calculation can only be displayed in the form of a percentage as in Table 2.

Based on the previous information, we can see that the differences in calculating the costs that occur between incoterms FOB and CFR are located on the cost of Ocean Freight, i.e. the cost of Ocean Freight does not enter into the calculation of FOB, while the cost difference between FOB and CIF is located on the cost of Ocean Freight and Insurance Premium that is not included into the calculation of the FOB. Finally the difference between Incoterm CFR and CIF is located on the implementation of the premium insurance where in the incoterm CFR, premium insurance is not included into the calculation, while in CIF, it's included into the calculation.

In percentage terms, data showed more complex incoterms used affect the decline of percentage in small amount for each of the cost structure from number 1 to 15 , as an example of the material costs decline from $48.96 \%$ FOB, become $47.34 \%$ CFR and 47.29 percent CIF. This happens due to the addition of the cost of Ocean Freight and premium insurance.

The determination of incoterm type used more dominated and determined by buyer unless the type of class D incoterm i.e. DAP and DDP is a type of incoterm which avoided or not preferred by PT X, based on the following reasons :

1. The lower class Incoterms that in the life of the class E "Ex-works", will affect the less risk and working capital that must be issued by PT X, but on one side, PT. X cannot sell with international prices because the price is Ex-Works local prices and PT X could not get additional benefits from logistic dealing services and PT X only has a low bar gaining power, as buyers generally know the market. Therefore, buyers can compare the selling price of PT X with the selling price of similar industry in Indonesia and is able to switch if there is a difference in the price although small. Only one weakness of this method, i.e. importer must arrange all shipping and permissions in Indonesia, which they must pointed certain party that understand the problem of rules and delivery in Indoneisa, including the permissions to arrange exports in Indonesia, so this method is not preferred by importer.

2. Incoterms class F, especially Incoterms FOB is one of the most used and most preferred by the importers with the same reason with class E, but importer have advantages that can receive goods when located above the ship, this means of goods already in place with international jurisdiction, where the importer does not need to arrange the export permission and local transportation in the jurisdiction of Indonesia which they cannot understand plus the price is still local.

3. Incoterms class $\mathrm{C}$ is the most preferred by PT $\mathrm{X}$, because besides it can sell goods with higher prices (international standards), PT X can also reach benefit from logistic dealing services until the destination port.

4. Incoterms Class D is avoided by PT X and the buyer. For PT X, sales by Incoterms D especially DDP allow to obtain greater than the selling price in the buyer country, but PT X does not have the understanding of the process of applying import, tax and shipping in the buyers country. On the contrary, for buyers, although small risk, this type is not preferred due to the selling price of imposed PT X (exporters) will be high, so that the benefits of the buyers will be reduced.

Table 3. Comparison of the level of operating profit for each type of Incoterms company

\begin{tabular}{ccccc}
\hline No & $\begin{array}{c}\text { Description } \\
\text { of Fees }\end{array}$ & FOB\% & CFR\% & CIF\% \\
\hline 19 & profit & $13.04 \%$ & $13.04 \%$ & $13.04 \%$ \\
\hline
\end{tabular}

Source : Data processed

The profit comparisons on each Incoterms used in percentage are shown in Table 3. It is the same of $13.04 \%$, but the currency value will be different and is not suitable because in CIF Incoterms, $13.04 \%$ will be multiplied by the numbers that is larger compared with the CFR and FOB. Greater multiplier factor numbers appears due to the more complex incoterms the company used will affect the more significant costs used, the bigger the cost used will affect the greater the profit is used because the profit wearing progressive method.

On the other hand, more complex Incoterms used will be in relation to the straight way with the greater effort or resource that is used as an example if companies use incoterms CIF. Therefore, the company must have an understanding of the problem of shipping and insurance. If the company is not able to cover an understanding under its company or does not complete the document resulted in the payment disruption by the bank, it would possibly give influence because of its late delivering goods and reduce the company's credibility, both for buyer or importer.

\section{CONCLUSION}

Based on the analysis and the discussion done previously, it can be concluded that:

1. Export price in PTX is determined by buyer, therefore the most Incoterms used is the most appropriate for buyers that is FOB Incoterms gradation from the lowest class to the highest is E, F, C and D 
2. Incoterms Class $\mathrm{C}$ for $\mathrm{PT} \mathrm{X}$ is able to provide greater advantages compared with the Incoterms Class F, or in other words the higher grade Incoterms used will have a positive effect on the benefits of PT X and vice versa.

\section{REFERENCES}

Astuti Purnamawati, S. F. 2013. Dasar-dasar Ekspor Impor. Yogyakarta. UPP STIM

Amir M.S. 2008. Handbook of Export-Import Business. Jakarta. PPM.

International Chamber of Commerce. History of the Incoterms rules. 2010a [cit. 2010-05-04]. Retrieved from: http://www.iccwbo.org/incoterms history.

International Chamber of Commerce. Incoterms 2010. 2010b. Paris, France: ICC Services Publications, ISBN 9284200806.
International Chamber of Commerce. ICC Uniform Customs and Practice for Documentary Credits, 2007 revision. 2006. Paris, France: ICC Services Publications Department. ISBN 928421257X.

Lazar, A. 2011. The Incoterms Rules and their importance. Judicial Tribune, 144.

Roberto Bergami, D. 2012. Incoterms 2010 : The Newest Revision of Delivery Terms. Acta Univ. Bohem, 34.

Surono, 2012, Mengenal Incoterms 2010: Instrumen Pengaturan Swasta yang Menjadi Rujukan Para Praktisi Perdagangan Internasional, Widyaiswara Pusdiklat Bea dan Cukai, Jakarta.

Susilo, Andi. 2013. Shipping: Panduan Pintar Ekspor Impor. Jakarta. Transmedia.

Suyono, C. R. 2003. Shipping. Jakarta: PPM.

Swastha, B. (2009). Manajemen Pemasaran 2. Yogyakarta. Adityamedia.

\section{APPENDIX}

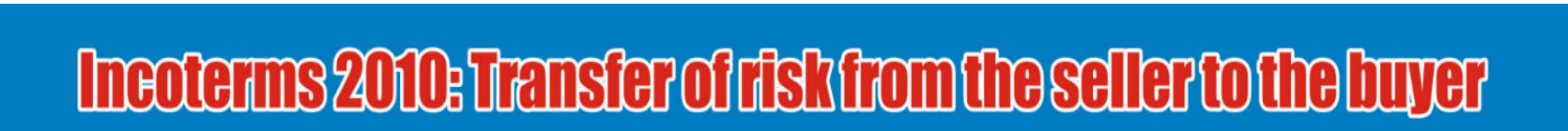

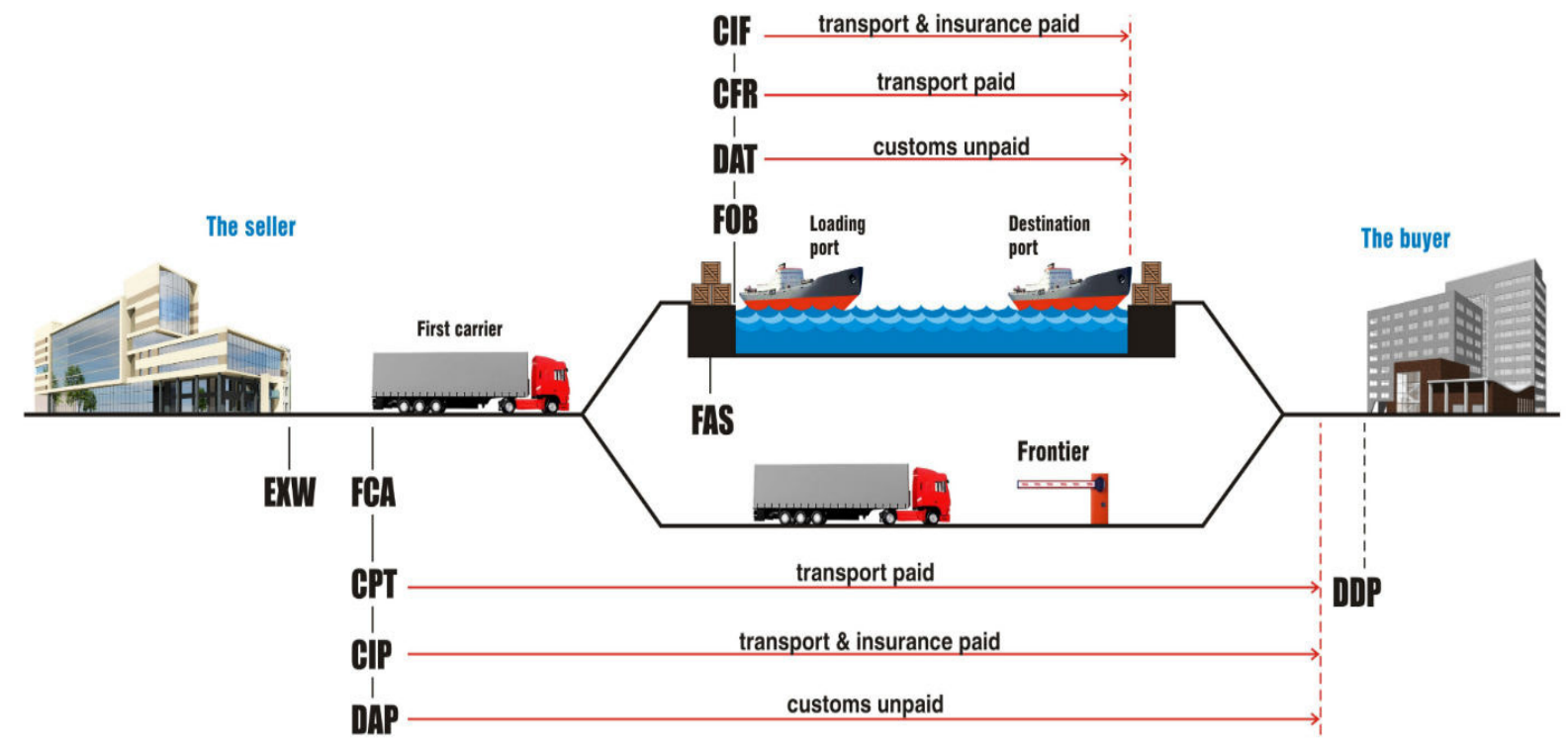

Source : (Incoterms 2010 Rules)

Figure 1. The point of the handover of goods and transfer of risk in Incoterms 2010 


\begin{tabular}{|c|c|c|c|c|c|c|c|c|c|c|c|}
\hline \multirow{3}{*}{$\frac{\text { INCOTERM AND }}{\text { SERVICES }}$} & EXW & FCA & CPT & CIP & DAT & DAP & DDP & FAS & FОВ & CFR & CIF \\
\hline & Ex Works & Free Carrier & $\begin{array}{l}\text { Carriage } \\
\text { Paid to }\end{array}$ & $\begin{array}{l}\text { Carriage } \\
\text { Insurance } \\
\text { Paid to }\end{array}$ & $\begin{array}{l}\text { Delivered at } \\
\text { Terminal }\end{array}$ & $\begin{array}{l}\text { Delivered at } \\
\text { Place }\end{array}$ & $\begin{array}{l}\text { Delivered Duty } \\
\text { Paid }\end{array}$ & $\begin{array}{l}\text { Free Alongside } \\
\text { Ship }\end{array}$ & $\begin{array}{l}\text { Free Onboard } \\
\text { Vessel }\end{array}$ & $\begin{array}{l}\text { Cost \& } \\
\text { Freight }\end{array}$ & $\begin{array}{l}\text { Cost Insurance } \\
\text { \& Freight }\end{array}$ \\
\hline & $\begin{array}{l}\text { Name Place } \\
\text { of Delivery }\end{array}$ & $\begin{array}{l}\text { Named Place } \\
\text { of Delivery }\end{array}$ & $\begin{array}{l}\text { Named Place } \\
\text { of Destination }\end{array}$ & $\begin{array}{l}\text { Named Port of } \\
\text { Destination }\end{array}$ & $\begin{array}{c}\text { Named } \\
\text { Terminal at } \\
\text { Port or Place of } \\
\text { Destination }\end{array}$ & $\begin{array}{l}\text { Named Place } \\
\text { of Destination }\end{array}$ & $\begin{array}{l}\text { Named Place of } \\
\text { Destination }\end{array}$ & $\begin{array}{l}\text { Named Port of } \\
\text { Shipment }\end{array}$ & $\begin{array}{l}\text { Named Port of } \\
\text { Shipment }\end{array}$ & $\begin{array}{c}\text { Named Port } \\
\text { of Destination }\end{array}$ & $\begin{array}{l}\text { Named Port of } \\
\text { Destination }\end{array}$ \\
\hline \multirow[t]{2}{*}{ Mode of Transport } & All Modes & All Modes & All Modes & All Modes & All Modes & All Modes & All Modes & $\begin{array}{c}\text { Ocean } \\
\text { Transport }\end{array}$ & $\begin{array}{l}\text { Ocean } \\
\text { Transport }\end{array}$ & $\begin{array}{l}\text { Ocean } \\
\text { Transport }\end{array}$ & $\begin{array}{l}\text { Ocean } \\
\text { Transport }\end{array}$ \\
\hline & Who Pays & Who Pays & Who Pays & Who Pays & Who Pays & Who Pays & Who Pays & Who Pays & Who Pays & Who Pays & Who Pays \\
\hline Export Packing & Seller & Seller & Seller & Seller & Seller & Seller & Seller & Seller & Seller & Seller & Seller \\
\hline $\begin{array}{l}\text { Export Clearance, } \\
\text { Licences and other } \\
\text { Authorization }\end{array}$ & Buyer & Seller & Seller & Seller & Seller & Seller & Seller & Seller & Seller & Seller & Seller \\
\hline $\begin{array}{l}\text { Container/Vehicle } \\
\text { Loading }\end{array}$ & Buyer & Seller & Seller & Seller & Seller & Seller & Seller & Seller & Seller & Seller & Seller \\
\hline Inland Freight & Buyer & $*^{*}$ Seller/Buyer & Seller & Seller & Seller & Seller & Seller & Seller & Seller & Seller & Seller \\
\hline Main Carrier Loading & Buyer & Buyer & Seller & Seller & Seller & Seller & Seller & Buyer & Seller & Seller & Seller \\
\hline Origin Terminal Charges & Buyer & Buyer & Seller & Seller & Seller & Seller & Seller & Buyer & Seller & Seller & Seller \\
\hline Insurance & No Obligation & No Obligation & No Obligation & Seller & No Obligation & No Obligation & No Obligation & No Obligation & No Obligation & No Obligation & Seller \\
\hline Freight & Buyer & Buyer & Seller & Seller & Seller & Seller & Seller & Buyer & Buyer & Seller & Seller \\
\hline $\begin{array}{c}\text { Destination Arrival } \\
\text { Charges }\end{array}$ & Buyer & Buyer & Seller & Seller & Seller & Seller & Seller & Buyer & Buyer & Buyer & Buyer \\
\hline Main Carrier Unloading & Buyer & Buyer & Buyer & Buyer & Seller & Seller & Seller & Buyer & Buyer & Buyer & Buyer \\
\hline $\begin{array}{l}\text { Import Customs } \\
\text { Clearance }\end{array}$ & Buyer & Buyer & Buyer & Buyer & Buyer & Buyer & Seller & Buyer & Buyer & Buyer & Buyer \\
\hline Duty \& Taxes & Buyer & Buyer & Buyer & Buyer & Buyer & Buyer & Seller & Buyer & Buyer & Buyer & Buyer \\
\hline Delivery to Destination & Buyer & Buyer & Buyer & Buyer & Buyer & Seller & Seller & Buyer & Buyer & Buyer & Buyer \\
\hline Seller/Buyer & $\begin{array}{l}\text { * There are } \\
\text { where the }\end{array}$ & $\begin{array}{l}\text { actually two FCA } \\
\text { eller is responsibl }\end{array}$ & $\begin{array}{l}\text { erms: FCA Seller } \\
\text { for inland freight. }\end{array}$ & emises where t & eller is respons & only for loading & he goods and not & ponsible for inla & freight; and FCA & Named Place (Inte & nasional Carrier) \\
\hline No Obligation & Neither the & Seller or the Buy & have an obligatio & to secure cargo in & urance however u & on request, the $\mathrm{Bu}$ & er or Seller must $\mathrm{pp}$ & ovide information & ecessary to obtain & insurance by the $r$ & questing party. \\
\hline
\end{tabular}

Source : Global Services.Inc., 2012

Figure 2. The outline of the responsibility of the cost in the Incoterms 2010

Table 2. Determination of PT X export price based on Incoterms 2010

\begin{tabular}{clccc}
\hline No & \multicolumn{1}{c}{ Cost Description } & FOB (\%) & CFR (\%) & CIF (\%) \\
\hline 1 & Cost of the Container Deport & $0.26 \%$ & $0.25 \%$ & $0.25 \%$ \\
2 & Material Cost & $48.96 \%$ & $47.34 \%$ & $47.29 \%$ \\
3 & Labor Cost & $19.58 \%$ & $18.94 \%$ & $18.91 \%$ \\
4 & Overhead Cost & $10.82 \%$ & $10.47 \%$ & $10.45 \%$ \\
5 & Packaging Material & $0.64 \%$ & $0.62 \%$ & $0.62 \%$ \\
6 & Cost of Label Print & $0.14 \%$ & $0.14 \%$ & $0.14 \%$ \\
7 & Cost of Stuffing & $0.13 \%$ & $0.12 \%$ & $0.12 \%$ \\
8 & Cost of Loading & $0.22 \%$ & $0.21 \%$ & $0.21 \%$ \\
9 & Transportation Cost & $0.90 \%$ & $0.87 \%$ & $0.87 \%$ \\
10 & Cost of Customs Clearance & $0.09 \%$ & $0.09 \%$ & $0.09 \%$ \\
11 & Cost of the Port & $1.39 \%$ & $1.35 \%$ & $1.34 \$$ \\
12 & Terminal Handling Charge & $0.52 \%$ & $0.51 \%$ & $0.51 \%$ \\
13 & Cost of B/L Fee & $0.15 \%$ & $0.14 \%$ & $0.14 \%$ \\
14 & Cost of Making Certificate of Origin & $0.06 \%$ & $0.06 \%$ & $0.06 \%$ \\
15 & Cost of Surveyor & $0.54 \%$ & $0.52 \%$ & $0.52 \%$ \\
16 & Cost of Ocean Freight & $0.00 \%$ & $2.79 \%$ & $2.79 \%$ \\
17 & Insurance Premium & $0.00 \%$ & $0.00 \%$ & $0.10 \%$ \\
18 & Bank Rate & $2.53 \%$ & $2.53 \%$ & $2.53 \%$ \\
19 & Profit & $13.04 \%$ & $13.04 \%$ & 13.045 \\
20 & Export price & $100.00 \%$ & $100.00 \%$ & $100.00 \%$ \\
\hline
\end{tabular}

Source : Data processed 